\title{
Avian Diversity of Oak Mixed Forest in Pauri Garhwal, Uttarakhand, India
}

Jarnail Singh $^{1} \cdot$ Sunil Bhandari ${ }^{1^{*}} \cdot$ M S Bisht $^{1}$

${ }^{1}$ Department of Zoology, HNB Garhwal University (A Central University), BGR Campus Pauri Garhwal-246001

*Corresponding author: sunilbhandari83@yahoo.in

Received: 24.102921; Revised: 14.11.2021; Accepted: 28.11.2021

(C)Society for Himalayan Action Research and Development

\begin{abstract}
The avian diversity of Oak mixed forest in Pauri Garhwal district of Uttarakhand was studied during October 2019 to March 2020. Two strands of oak mixed forest located at different sites at $29^{\circ} 22^{\prime}-29^{\circ} 75^{\prime}$ North and $78^{\circ}, 10^{\prime}-78^{\circ}, 80^{\prime}$ East (1750 masl) were selected. Regular field survey was carried out during the morning and evening hours at each site. A total of 63 species of birds belonging to 07 orders and 31 families were recorded. The average bird diversity index $\mathrm{H}^{-}$was 3.202. The species richness was observed around 7.27 and species evenness was 0.72 . The highest number of species was recorded at Ransi Oak mixed forest (63) and lowest number of bird species were recorded in Teka Oak mixed forest (60).
\end{abstract}

Key words: Avian diversity, Diversity index, Species richness, Evenness, Oak mixed forest

Introduction

Birds are one of the best known and highly valued groups of species. They are a group of feathered, biped, warm blooded animals whose body temperature remains more or less constant and independent of surrounding temperature. The birdlife in India is truly amazing that contributes an important part to biodiversity. These are found in all the continents, seas and inlands penetrating the arctic beyond $30^{\circ}$ North and over $6400 \mathrm{~m}$ altitude on Mount Everest (Singh and Bhasker, 2003). The wide occurrence is due to their power of flight, which enable them to reach in accessible area. There are about 10,000 species of birds in the world and out of these India contributes nearly 1250 species $(12.5 \%)$ of the world total avian diversity (Gill and Dhonsker, 2019). Garhwal Himalaya as a part of Western Himalaya is rich for its habitat diversity and bird species richness due to its unique position between indo-Chinese and Paleacritic lines and great altitudinal variation from $400 \mathrm{~m}$ to $7817 \mathrm{~m}$ (Nanda Devi Peak II). Therefore, present study was aimed to record avian diversity of Oak mixed forest of district Pauri Garhwal. Oak mixed forest are the habitats of wild animals including birds and provide various essential services such as medicine, food, timber, shelter, grasses, fresh oxygen and promotion of ecotourism.

\section{Material and Methods}

The present study was conducted in district Pauri Garhwal Uttarakhand which lies in the Western Himalaya between $29^{\circ} 22^{\prime}-29^{\circ}$ $75^{\prime}$ North and $78^{\circ}, 10^{\prime}$ to $78^{\circ}, 80^{\prime}$ East and at an altitude of 1750masl. Two sites of Oak mixed forest were selected constituted by Quercus, Rhododendron, Myrica, Cedrus, Pinus etc. at 
Ransi and Teka (Table 1). The survey was carried out from October 2019 to March 2020; both sites were visited in each month. Following the Line transect and Point count methods (Javed and Kaul, 2002; Bibby et al., 2000), the birds were recorded at each site. With the help of field binocular ( $2 \times 40 \mathrm{X})$ and pocket field guides (Gremmitt et. al., 2011, Ali and Replay 2002), each bird was identified and photographed by digital Camera (21.1 mp x 63X zoom). The diversity index, species richness and evenness of birds were calculated by using (Shannon and Weaver diversity index 1949), Margalef index (1968). Field survey conducted during the harsh weather conditions and rainy seasons were not considered in the results.

\section{Results and Discussions}

During the survey, a total of 63 species of birds belonging to 07 orders and 31 families were recorded (Table 2). The highest numbers of species were recorded under the order Passeriformes (75\% species composition) and lowest in the order Galliformes and Strigiformes (Table 2 and Fig. 1). Among families, the highest species of birds were recorded in family Muscipidae (20\% species composition) and the lowest were recorded in the family Phasinaidae, Strigidae, Dicruridae, Rhipiduridae, Timalidae, Sittidae, Fringillidae, Eberzidae, Zoosterpidae and Tichodromidae (Table-3 and Fig. 2). Therefore, the strong positive correlation between total number of species and total number of orders and families was observed (Fig. 3 and 4). From out of the total observed birds, 07 species were identified as summer visitors and 05 species as winter visitors (Table4 and 5).

The highest numbers of bird species (63) was recorded at Ransi and Lowest was recorded at Teka (60). The overall diversity index of birds in Oak mixed forest of Pauri Garhwal was found $\left(\mathrm{H}^{-}=3.202\right)$, species richness (7.27) and species evenness 0.72 (Table 6). Out of the total birds recorded in the study area, one species Steppe eagle was endangered, four species Emerald dove Tickells leaf warbler, Greater yellownape and Indian nuthatch are rare, two species Black headed jay and White napped tit are vulnerable (IUCN, 2015, 2018, 2019) (Fig. 5). Besides this, five species Emerald dove, White crested kalij, Black headed jay, Himalayan bulbul are endemic to Western Himalaya.

Table 1. Bird species recorded at different sites in oak mixed forests of Pauri Garhwal, Himalaya.

\begin{tabular}{clcccc}
\hline S. $\mathbf{N}$ & Site Names & Altitude & TO & TF & TS \\
\hline 1 & Ransi Oak mixed Forest & $1890 \mathrm{~m}$ & 07 & 32 & 63 \\
2 & Teka Oak mixed Forest & $1750 \mathrm{~m}$ & 07 & 29 & 60
\end{tabular}

Abbreviations: TO-Total Order, $\boldsymbol{T F}$ - Total Families, TS- Total Species 
Table 2. Check list of bird fauna of the Oak mixed forest of Pauri town Garhwal Western Himalaya

\begin{tabular}{|c|c|c|c|c|}
\hline $\begin{array}{l}\text { S. } \\
\text { No. }\end{array}$ & Name of Bird/Order /Family & Zoological Name & $\begin{array}{c}\text { Relative } \\
\text { abundance }\end{array}$ & $\begin{array}{l}\text { Distribution } \\
\text { Range }\end{array}$ \\
\hline $\mathbf{I}$ & GALLIFORMES & & & \\
\hline a) & Phasinaidae & & & \\
\hline 1 & White crested Kalij & Lophura leucomelones & 0.037 & Up to 3700 \\
\hline II & COLUMBIFORMES & & & \\
\hline a) & Columbidae & & & \\
\hline 2 & Oriental turtle dove & Stigmatopelia orgnatalis & 0.027 & Up to 4000 \\
\hline 3 & Spotted dove & Stigmatopelia chinensis & 0.012 & Up to 4000 \\
\hline 4 & Emerald dove & Chalcophaps indica & 0.014 & $<1800$ \\
\hline 5 & Blue rock pigeon & Columba livia & 0.015 & $<3300$ \\
\hline III & PSITACIFORMES & & & \\
\hline a) & Psititidae & & & \\
\hline 6 & Slaty headed parakeet & Psittacula himalayana & 0.049 & $600 t 02500$ \\
\hline 7 & Plum headed parakeet & Pisttacula cypnonephala & 0.038 & $<1500$ \\
\hline 8 & Grey headed parakeet & Pisttacula finschii & 0.025 & $<1500$ \\
\hline IV & STRIGIFORMES & & & \\
\hline a) & Strigidae & & & \\
\hline 9 & Jungle owlet & Glaucidium radiatum & 0.0033 & $<2000$ \\
\hline $\mathbf{V}$ & PICIFORMES & & & \\
\hline a) & Captonidae & & & \\
\hline 10 & Great barbet & Magalaima virens & 0.021 & 1000 to 3000 \\
\hline 11 & Blue throated barbet & Megalaima asiatica & 0.066 & 1000 to 3000 \\
\hline b) & Piccidae & & & \\
\hline 12 & Grey capped pygmy woodpecker & Dendronopos canicapillus & 0.016 & $<1700$ \\
\hline 13 & Brown fronted woodpecker & Dendronopos auricops & 0.019 & 1000 to 3100 \\
\hline 14 & Greater yellow nap & Picus chlorolopes & 0.02 & $<2100$ \\
\hline 15 & Rufous bellied woodpecker & Dendronopos hyperythrus & 0.028 & $<1500$ \\
\hline VI & PASSERIFORMES & & & \\
\hline a) & Hirundunidae & & & \\
\hline 16 & Red rumped swallow & Cecropis daurica & 0.0078 & Upto 3000 \\
\hline 17 & Barn swallow & Hirundo rustica & 0.051 & Upto 3000 \\
\hline b) & Dicruridae & & & \\
\hline 18 & Black drongo & Dicrurus macrocercus & 0.0091 & $<2100$ \\
\hline c) & Sturnidae & & & \\
\hline 19 & Common myna & Acridotheres tristis & 0.031 & $<3050$ \\
\hline 20 & Jungle myna & Aeridotheres fuscus & 0.013 & $<2400$ \\
\hline
\end{tabular}




\begin{tabular}{|c|c|c|c|c|}
\hline d) & Coraciidae & & & \\
\hline 21 & Black headed jay & Garrulus lanceolatus & 0.038 & 900 t0 2500 \\
\hline 22 & Euration jay & Garrulus glandarius & 0.03 & 1500 to 3000 \\
\hline e) & Corvidae & & & \\
\hline 23 & Grey treepie & Deudrocitta formorae & 0.016 & 600 to 2100 \\
\hline 24 & Red billed blue magpie & Urocissa erythrohyncha & 0.026 & Up to 2000 \\
\hline 25 & Yellow billed blue magpie & Urocissa flauisostris & 0.033 & 1000 \\
\hline 26 & Jungle crow & Corvus macrohynchos & 0.023 & 1600 \\
\hline f) & Campehagidae & & & \\
\hline 27 & Scarlet minivet & Pericrocotus flammesns & 0.006 & 2700 \\
\hline g) & Pycnonotidae & & & \\
\hline 28 & Black bulbul & Hypsipetes leucocephalus & 0.022 & 3000 \\
\hline 29 & Himalayan bulbul & Pycmotus leucogenys & 0.062 & 300 to 2400 \\
\hline 30 & Red vented bulbul & Pycmotus cafer & 0.049 & 1500 \\
\hline h) & Muscicapidae & & & \\
\hline 31 & Verditer flycatcher & Eumfias thalassium & 0.0057 & 1200 t0 2700 \\
\hline 32 & Dull blue flycatcher & Eumfias rordidus & 0.002 & 900 to 2100 \\
\hline 33 & Grey headed canary flycatcher & Culicipa ceylonensis & 0.0067 & $<2700$ \\
\hline 34 & Yellow rumped flycatcher & Ficedula zanthropygia & 0.0033 & $<400$ \\
\hline 35 & Common stone chat & Saxicola torquatus & 0.008 & $<1800$ \\
\hline 36 & Grey bush chat & Saxicola ferreus & 0.01 & 1200 t0 3000 \\
\hline i) & Turdidae & & & \\
\hline 37 & Blue whistling thrush & Myophonus caerulous & 0.027 & 1500 t0 2400 \\
\hline 38 & Grey winged black bird & Turdus boulboul & 0.034 & 1800 to 2700 \\
\hline j) & Rhipiduridae & & & \\
\hline 39 & White throated fantail & Rhipidura albicollis & 0.009 & $<1700$ \\
\hline k) & Timilidae & & & \\
\hline 40 & Rusty checked scimitar bubbler & Pomatorhimiseythronemis & 0.0033 & 750 to 1800 \\
\hline l) & Sittidae & & & \\
\hline 41 & Chest nut bellied nuthatch & Sitta castanea & 0.0072 & 1200 to 2800 \\
\hline m) & Certhiidae & & & \\
\hline 42 & Brown throated tree creeper & Certhia discolor & 0.012 & 700 to 3200 \\
\hline 43 & Bar tailed tree creeper & Certhia himalayana & 0.013 & $<1500$ \\
\hline n) & Paridae & & & \\
\hline 44 & Black lored tit & Parus xanthogenys & 0.0057 & $<2400$ \\
\hline 45 & White napped tit & Parus muchalis & 0.0042 & $<1200$ \\
\hline 46 & Yellow checked tit & Parus aplontus & 0.0028 & 1200 to 2400 \\
\hline 47 & Black throated tit & Aegitholos concinnus & 0.0072 & 1200 to 2400 \\
\hline
\end{tabular}

o) Pemizidae 


\begin{tabular}{rllll}
48 & Fire capped tit & Cephalopyrus flammicepus & 0.01 & 2000 to 3500 \\
\hline p) & Cisticolidae & Phyllocopes affinis & 0.0038 & 3300 t0 4500 \\
49 & Tickle's leaf warbler & Phyllocopes xanthosohistos & 0.0057 & 1000 t0 2300 \\
50 & Grey hooded warbler & Phyllocopes reguloids & 0.0058 & $<1200$ \\
51 & Blyth's leaf warbler & Phyllorgales trochiloids & 0.0056 & 2600 t0 4000 \\
52 & Greenish warbler & & & \\
\hline q) & Silividae & Garrulax lincatus & 0.061 & $<1200$ \\
53 & Streaked laughing thrush & Garrulax albogulasis & 0.022 & 1800 t0 3300 \\
54 & White laughing thrush & & &
\end{tabular}

\begin{tabular}{|c|c|c|c|c|}
\hline r) & Passeridae & & & \\
\hline 55 & House sparrow & Passer domestians & 0.066 & $<4000$ \\
\hline 56 & Russet sparrow & Passer rutilans & 0.023 & 500 to 2700 \\
\hline s) & Motacilliadae & & & \\
\hline 57 & Grey wagtail & Moticilla cinerea & 0.0017 & $<1800$ \\
\hline t) & Fringillidae & & & \\
\hline 58 & Yellow breasted green finch & Carduelis spinodes & 0.0033 & 900 to 4400 \\
\hline v) & Embrizidae & & & \\
\hline 59 & Rock bunting & Emberizacia & 0.0057 & 600 to 4600 \\
\hline u) & Zosteropidae & & & \\
\hline 60 & Oriented white eye & Zosterops palpebrosus & 0.0097 & $<1800$ \\
\hline v) & Tichodromidae & & & \\
\hline 61 & Wall creeper & Tricodroma murasia & 0.0055 & $<3300$ \\
\hline VII & FALCONIFORMS & & & \\
\hline a) & Accipitiridae & & & \\
\hline 62 & Himalayan vulture & Gyps himalayensis & 0.0037 & 900 to 4000 \\
\hline 63 & Steppe eagle & Aquila nipalensis & 0.0034 & $<1500$ \\
\hline
\end{tabular}

Table 3. Composition of bird species under different order

\begin{tabular}{clcc}
\hline S.N & Order & No. of Species & Species Composition \% \\
\hline 1 & Galliformes & 01 & $1.59 \%$ \\
2 & Columbiformes & 04 & $6.35 \%$ \\
3 & Psittaciformes & 03 & $4.76 \%$ \\
4 & Strigiformes & 01 & $1.58 \%$ \\
5 & Passeriformes & 45 & $71.43 \%$ \\
6 & Piciformes & 06 & $9.52 \%$ \\
7 & Falconiformes & 03 & $4.76 \%$ \\
\hline
\end{tabular}


Among families, the highest species of birds were recorded in family Muscipidae (20\% species composition) and the lowest were recorded in the family Phasinaidae, Strigidae, Dicruridae, Rhipiduridae, Timalidae, Sittidae, Fringillidae, Eberzidae, Zoosterpidae and Tichodromidae (Table-4 and Fig. 2). Therefore, the strong positive correlation between total number of species and total number of orders and families was observed (Fig. 3 and 4). From out of the total observed birds, 07 species were identified as summer visitors and 05 species as winter visitors (Table- 5 and 6).

Table 4. Composition of bird species under different families

\begin{tabular}{clcc}
\hline S.N & Family & No. of Species & Species Composition (\%) \\
\hline 1 & Phasinaidae & 01 & $1.59 \%$ \\
2 & Columbidae & 04 & $6.35 \%$ \\
3 & Psititidae & 03 & $4.76 \%$ \\
4 & Strigidae & 01 & $1.59 \%$ \\
5 & Captonidae & 02 & $3.17 \%$ \\
6 & Piccidae & 04 & $6.35 \%$ \\
7 & Hirundunidae & 02 & $3.17 \%$ \\
8 & Dicruridae & 01 & $1.59 \%$ \\
9 & Sturnidae & 02 & $3.17 \%$ \\
10 & Coraciidae & 02 & $3.17 \%$ \\
11 & Corvidae & 04 & $6.35 \%$ \\
12 & Campehagidae & 01 & $1.59 \%$ \\
13 & Pycnonotidae & 03 & $4.76 \%$ \\
14 & Muscicapidae & 06 & $9.52 \%$ \\
15 & Turdidae & 02 & $3.17 \%$ \\
16 & Rhipiduridae & 01 & $1.59 \%$ \\
17 & Timilidae & 01 & $1.59 \%$ \\
18 & Sittidae & 01 & $1.59 \%$ \\
19 & Certhiidae & 02 & $3.17 \%$ \\
20 & Paridae & 04 & $6.35 \%$ \\
21 & Pemizidae & 01 & $1.59 \%$ \\
22 & Cisticolidae & 04 & $6.35 \%$ \\
23 & Silividae & 02 & $3.17 \%$ \\
24 & Leiothrichidae & 01 & $1.59 \%$ \\
25 & Passeridae & 02 & $3.17 \%$ \\
26 & Motacilliadae & 01 & $1.59 \%$ \\
27 & Fringillidae & 01 & $1.59 \%$ \\
28 & Embrizidae & 01 & $1.59 \%$ \\
29 & Zosteropidae & 01 & $1.59 \%$ \\
30 & Accipiteridae & 01 & $1.59 \%$ \\
31 & Tichodromidae & 01 & $1.59 \%$ \\
\hline & & & \\
\hline
\end{tabular}

Table 5. Summer visitor birds recorded in the Oak mixed forest of Pauri Garhwal 


\begin{tabular}{cll}
\hline S. No & Name Of Bird Species & Zoological Name \\
\hline $\mathbf{1}$ & Plum headed parakeet & Psittacula cyanocephala \\
$\mathbf{2}$ & Black drongo & Dicrurus leucophaeus \\
$\mathbf{3}$ & Oriental turtle dove & Streptopelia \\
$\mathbf{4}$ & Ultramarine flycatcher & Orientalis \\
$\mathbf{5}$ & Common myna & Acridotheres triestis \\
$\mathbf{6}$ & Dull blue fly catcher & Eumyias sordidus \\
$\mathbf{7}$ & Mountain tailor bird & Phyllegates cuculatus \\
\hline
\end{tabular}

Table 6. Winter visitor birds recorded in the Oak mixed forest of Pauri Garhwal

\begin{tabular}{cll}
\hline S. $\mathbf{N}$. & Name of Bird Species & Zoological Name \\
\hline $\mathbf{1}$ & Lesser yellow nape & Picus chlorolophus \\
$\mathbf{2}$ & Rock bunting & Emberiza cia \\
$\mathbf{3}$ & White checked tit & Aegithalos leucogenys \\
$\mathbf{4}$ & Wall creeper & Tichodroma muraria \\
$\mathbf{5}$ & White throated laughing thrush & Garrulax albogularis \\
\hline
\end{tabular}

Table 7. Monthly average records of bird species in oak mixed forest at Pauri Garhwal.

\begin{tabular}{llccccccc}
\hline S.N & Months & TO & TF & TS & DI & SR & Evenness & $\begin{array}{c}\text { Simpson index } \\
(\mathbf{1 - D})\end{array}$ \\
\hline 1 & October & 07 & 31 & 57 & 1.8 & 4.41 & 0.44 & 0.96 \\
2 & November & 05 & 27 & 41 & 1.7 & 2.08 & 0.45 & 0.95 \\
3 & December & 06 & 29 & 54 & 1.7 & & 0.48 & 0.97 \\
4 & January & 06 & 28 & 45 & 1.3 & 2.34 & 0.34 & 0.97 \\
5 & February & 07 & 31 & 61 & 1.6 & 3.57 & 0.47 & 0.99 \\
6 & March & 07 & 31 & 63 & 1.9 & 3.39 & 0.49 & 0.98
\end{tabular}

Abbreviations: TO- Total orders, TF- Total families, TS- Total Species, DI- Diversity index, SR- Species richness

The highest numbers of bird species (63) was recorded at Ransi and Lowest was recorded at Teka (60). The overall diversity index of birds in Oak mixed forest of Pauri Garhwal was found $\left(\mathrm{H}^{-}=3.202\right)$, species richness (7.27) and species evenness 0.72
(Table 7). Out of the total birds recorded in the study area, one species Steppe eagle was endangered, four species Emerald dove Tickells leaf warbler, Greater yellownape and Indian nuthatch are rare, two species Black headed jay and White napped tit are 
vulnerable (IUCN, 2015, 2018, 2019) (Fig. Himalayan bulbul are endemic to Western 5). Besides this, five species Emerald dove, Himalaya.

White crested kalij, Black headed jay,

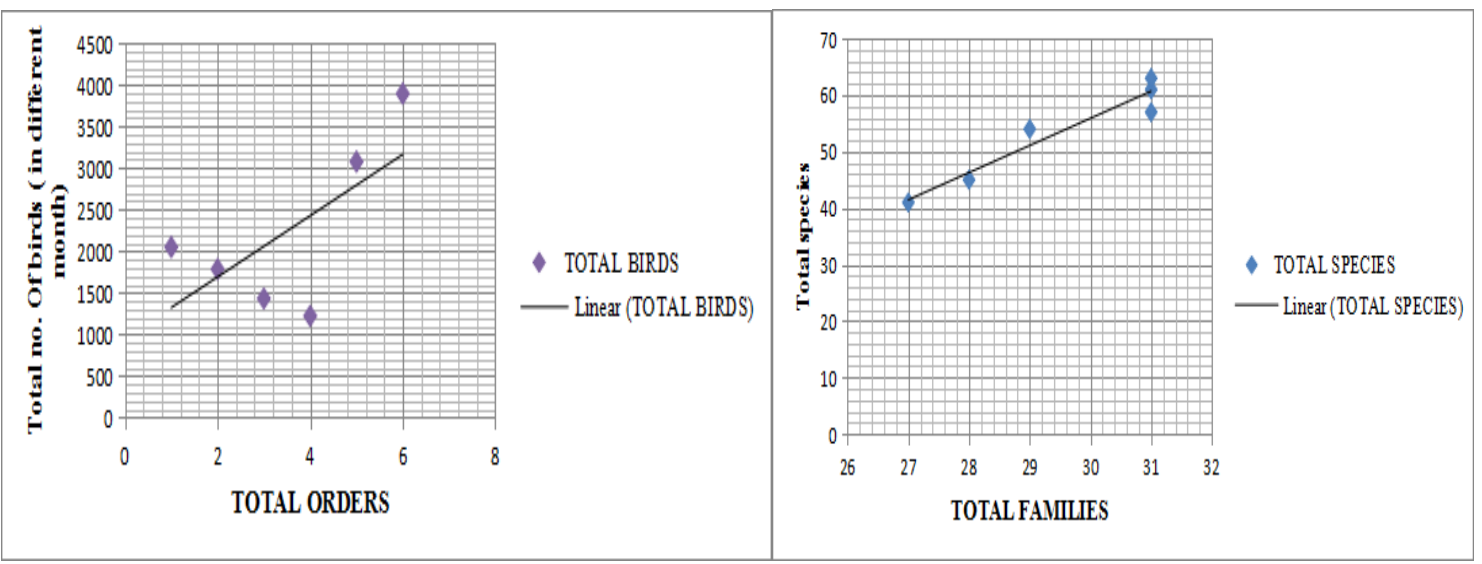

Fig. 3. Correlation between number of species and orders

Fig. 4. Correlation between number of species and families.

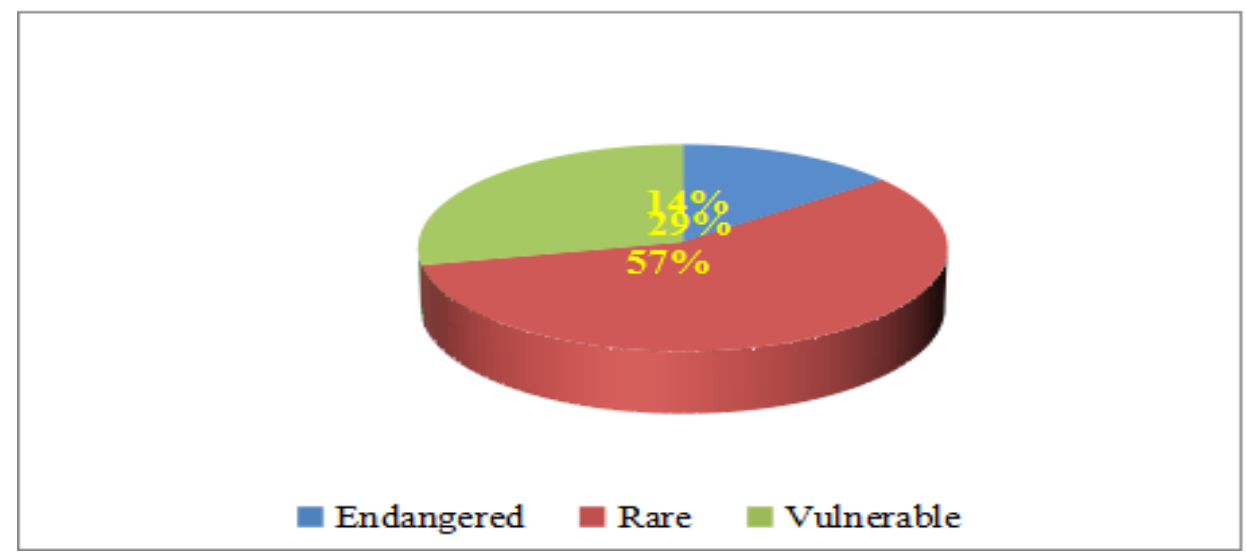

Fig.5. Birds under different IUCN Category

Findings of the present study suggest that the bird community structure of the oak mixed forest of Garhwal Himalaya also exhibit variations in time and is a function of the food as reported by (Sabo and Holmes, 1983; Mac Arthur, 1958, Holmes et al., 1986). Ecologically, birds have tremendous importance as they are important pollinators, 
scavengers and play a key role in seed dispersal. These are good indicators, as their presence is an indication of healthy ecosystem in habitats. The previous systematic studies on avian diversity, abundance and resistant status has been conducted on Kalij pheasant (ChandolaSaklani et al., 1988; Kumar et al., 2013,2016,2019), Himalayan monal (Bisht et al., 1989), Chukur partridge (Kukreti et al., 2005), Cheer pheasant (Bisht et al., 2005 and Phaurailatpum, 2005), avian diversity (Bisht et al., 2004; Bhandari and Bisht 2012, Bhandari et al., 2015, 2018). The birds of Himalayan region (Shafiq et al, 2000) and pioneering investigations to Ali, S.(1981) authoritative handbook of Himalayan region.

This study indicates the current status of community composition (abundance, richness, evenness, and diversity), status of endangered, rare and vulnerable bird species in oak mixed forest constituted by the dominant species of Quercus, Rhododendron, Myrica, Cedrus, Pinus, are under heavy anthropogenic pressure near human habitation which directly or indirectly effect the avian diversity. Despite, various anthropogenic activities, oak mixed forest still have good number of birds but some pheasants (Cheer pheasant and Partridges) were common in the past have not seen in the study area. Habitat destruction by deforestation, unusual forest fire, and invasive weeds like Eupatorium and Lantana camera are the main threats to biodiversity in the study area (Kumar et al., 2019). Therefore, the forest department and local people should properly look after the natural forests and necessary steps must be taken to ensure the well being of forests and associated bird diversity to be conserved in the future.

\section{Acknowledgement}

The authors are thankful to Prof. A. K. Dobriyal, Dean of Life Sciences, HNB Garhwal Central University and Head department of Zoology, BGR Campus Pauri Garhwal for his continuous support and encouragement.

\section{References}

Ali, S. and Ripley, S. D. (2002). Handbook of Bird of India and Pakistan. Compact edition, Oxford University Press, New Delhi.

Ali, S., (1981). The Himalaya in Indian Ornithology. In the Himalaya aspect 
of change. Oxford University Press, New Delhi.16-31.

Bhandari S, Kumar S and Bisht M S (2015). Avian Diversity of the Western Nayar Valley (Pauri Garhwal) Uttarakhand. J. Mountain Res. Vol. (10): Pp13-19.

Bhandari S, Kumar S and Bisht M S (2018). Status of Faunal Diversity In Nanda Devi National Park (NDNP): Chamoli, Uttarakhand India. J. Mountain Res. Vol. (13): Pp59-67.

Bhandari, S and Bisht, M. S. (2012). Studies on the community structure of avian fauna in relation to distribution of invasive vegetation in Garhwal Himalaya, Ph.D. thesis submitted to HNB Garhwal University Srinagar: 158

Bibby, C. J, Burgess N. D, Hill D. A. and Mustoe S. H. (2000). Birds census techniques. London: Academic Press: 302.

Bisht, M. S., Phurailatpam, S. and Kathait, B. S. (2005). Breeding ecology of Cheer pheasant Catreus wallichii in Garhwal Himalaya. Proceeding of $3^{\text {rd }}$ International Galliformes symposium. (Eds.) Fuller, R.A. and Browne, S. J. Fordingbridge, U.K. 188-191.

Bisht, M., Lakhera, P. and ChandolaSaklani, A. (1991). Himalayan monal pheasant: Current status and habitat utilization in the Kedarnath Sanctuary, Garhwal Himalaya. In (Eds.) Garson, P. J. and Jenkins, D. Pheasant in Asia. WPA, Reading U.K. 205-208.

Chandola-Saklani, A., Lakhera, P. and Bisht, M. S, (1988). Current status and distribution of some endangered and wide spread animals of the Garhwal Himalaya, Proc. III International Range land Congress, New Delhi, 2: 435:437.

Grimmett, R., Inskipp, C. and Inskipp, T. (2011). 'Birds of Indian subcontinents", $2^{\text {nd }}$ edition. Oxford University Press. New Delhi, 615.

Holmes, R.T., Shery, T. W. and Struges, F.W. (1986). Bird community dynamics in a temperate deciduous forest; long term trends at Hubbard brook. Ecol. Monogr. 56; 201-220. 
IUCN (2015). IUCN Red List of Threatened Species. iucnredlist. org.

\section{IUCN (2016). IUCN Red List of Threatened} Species.www.iucnredlist.org.

IUCN (2018). IUCN Red List of Threatened Species.www.iucnredlist.org.

Javed, S. and Kaul, R., (2002). Field Methods for Bird Surveys. Bomb. Nat. Hist. Soci. and World Pheasant Association, New Delhi, 61.

Kukreti, M., Phurailatpam, S. and Bisht, M. S. (2005). Ecology of Chukar Partridge Alectorischukar in Garhwal Himalaya.Proc. of $3^{\text {rd }}$ Int. Galliformes Symp. 4-7 $7^{\text {th }}$ April, Dehradun. Eds. Fuller, R.A. and Browne, S.J. World Pheasant Association, Fording bridge U.K. 195-198.

Kumar S, Bisht M.S. and Bhandari S (2016). Record of Species Diversity and Relative Abundance of Bird Fauna in Temperate Forests of District Pauri Garhwal, Uttarakhand. J. Mountain Res. Vol. (11): Pp 63-67.
Kumar S, Bisht M.S. and Bhandari S (2019). Bird Fauna of Temperate Forest of District Pauri Garhwal, Uttarakhand. Int. J. Res. Rew., Vol. 6 (1): Pp 1396-1404.

Kumar S. and Bhandari S. (2015). Survey of Bird Fauna of Nagdev Reserve Forest in District Pauri Garhwal, Uttarakhand, India J. Mountain Res. Vol. (10): Pp45-50.

Kumar, S., Bisht, M. S. and Kukreti. M. (2013). Social behavior of White crested Kalij pheasant Lophura leucomelanos hamilitonii (Grey) in Garhwal Himalaya. Cheetal, 51(1\&2): 20-28.

Mac Arthur, R. H. (1958). Population ecology of some warblers of north eastern coniferous forests.

Ecology. 76; 318-325.

Margalef, D. R. (1968). 'Perspective in ecological theory". University of Chicago Press. Chicago.

Phurailatpam, S. (2005). Some aspects of biology and population ecology of the endangered Cheer pheasant Catreus wallichiiin Garhwal Himalaya. Ph.D. Thesis submitted to 
HNB Garhwal University Srinagar

(Garhwal), Uttarakhand, India.

Sabo, S. R. and Holmes, R. T. (1983). Foraging niches and the structure of forest bird communities in contrasting montane habitat. Condor. $85 ; 121-138$

Shafiq, T., Javed, S. and Kaul, R. (2000). Himalayan mountain quail in India: living or extinct. Annual Rev. WPA, 46-52.

Shannon C. E. and Weaver W. (1949). The Mathematical Theory of Communication. University of Illinois Press; Urbana, IL, USA.

Singh, G. and Bhaskar, H., (2003). An Introduction to Birds. Campus International Publication, 242. 